\title{
Experimental Study on Landslides of Loose Sediment Slope Induced by Stream Bed Incision
}

\author{
Kehan Huang, Mengzhen $\mathrm{Xu}$ *and Zhaoyin Wang \\ State Key Laboratory of Hydroscience and Engineering, Tsinghua University, Beijing, China
}

OPEN ACCESS

Edited by:

Qihua Ran,

Zhejiang University, China

Reviewed by:

Songdong Shao,

Dongguan University of Technology,

China

Guoce Xu,

Xi'an University of Technology, China

*Correspondence:

Mengzhen Xu

mzxu@mail.tsinghua.edu.cn

Specialty section:

This article was submitted to Geohazards and Georisks,

a section of the journal

Frontiers in Earth Science

Received: 29 March 2021 Accepted: 28 May 2021

Published: 09 June 2021

Citation:

Huang K, Xu M and Wang Z (2021) Experimental Study on Landslides of Loose Sediment Slope Induced by

Stream Bed Incision.

Front. Earth Sci. 9:687358.

doi: 10.3389/feart.2021.687358
Uplift of the Qinghai-Tibetan Plateau has resulted in rapid incision of rivers along the margin of the plateau. Landslides occur frequently as a consequence of increasing bank slope and potential landslide energy due to stream bed incision or lateral bank erosion on the concave banks at bends. The Fencha Gully is on the eastern margin of the QinghaiTibetan Plateau and is developing on a huge landslide body. Flume experiments were conducted on the base of the field investigation to study the mechanism of landslides induced by stream bed incision. The experiments were designed with a length scale ratio of 1:20. Landslides and stream bed incision with loose sediment were observed and analyzed. The results show that landslides are induced as a result of stream bed incision. The potential landslide energy is defined, which increases quickly with an effective incision depth coupling vertical incision and lateral bank erosion. The occurrence of landslides can be attributed to increasing incision depth and potential landslide energy. Results indicate that the critical effective incision depth is 4.0-6.0 m. A critical value of the potential landslide energy is found from the experiments. Landslides occur if the potential energy exceeds the critical energy, which is $2.24 \times 10^{4} \mathrm{t} \cdot \mathrm{m} / \mathrm{s}^{2}$ for the Fencha Gully. The incision depth and potential energy of landslides from the Fencha Gully agree well with the results.

Keywords: landslides, stream bed incision, Qinghai-Tibetan Plateau, flume experiments, potential landslide energy

\section{INTRODUCTION}

Bed incision occurs widely in mountain rivers no matter with sediment-bed or rock-bed (Ouimet et al., 2008; Wohl, 2010; Berger et al., 2011; Hobley et al., 2011). The margin of Qinghai-Tibetan Plateau is one of the most rapidly uplifting and eroding regions on Earth, especially in the Hengduan Mountain Region. As shown in Figure 1, the rivers along the margin of the plateau are deeply incised and accompanied by frequent landslides and other forms of bank failures, triggering disaster chains and catastrophic damages in the regional scale (Ouimet et al., 2009, Ouimet et al., 2010; Xu et al., 2012; Kirschbaum et al., 2015; Zhao et al., 2019). Our field investigations show that many of these rivers are characterized by steep slope and loosely deposited bed and hillslopes (see Figures 1A-E).

The idea is well-recognized that landslide is triggered fundamentally by increasing weight and reduced shear strength (Azanon et al., 2005; Ouimet et al., 2007; Zhou et al., 2016). However, the incision still provide a fundamental inducement at the basin - or channel-scale, and therefore has become a major concern for mountain river management (Whipple, 2004; Safran et al., 2005; Wang et al., 2015). This can be interpreted as that with the lack of support from slope toe, the destabilization 

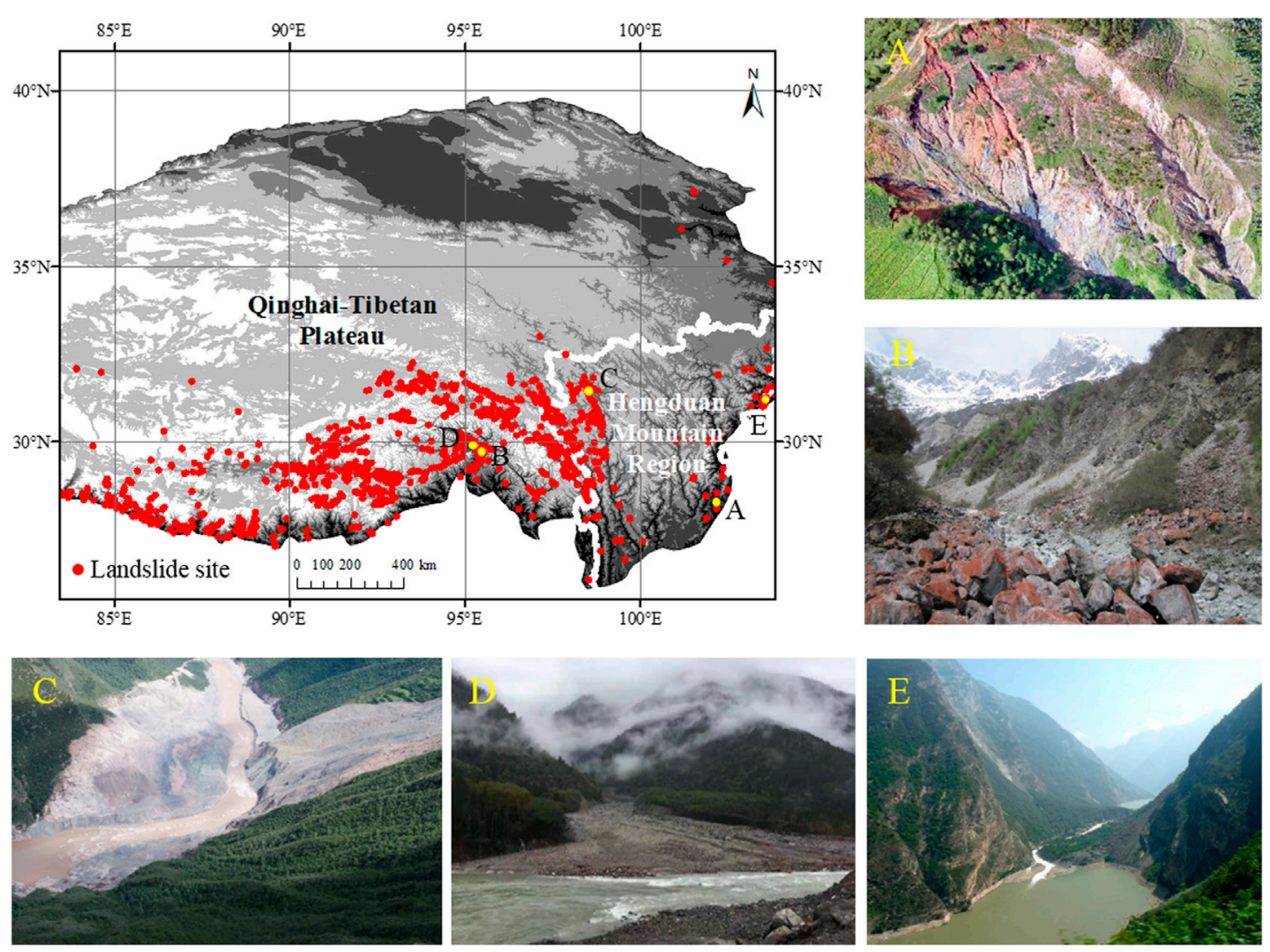

FIGURE 1 | Regional topography and landslide sites of the eastern and south-eastern margin of the Qinghai-Tibetan Plateau, and nature hazard: (A) rapid stream bed incision (Fencha Gully, photo by Kehan Huang in December 2020); (B) collapse (Guxiang Gully, photo by Liqun Lyu in May 2015); (C) landslides (Jinsha River, photo by Yunlong Lei in October 2019); (D) debris flow (Palong River, taken by Kehan Huang in October 2019); (E) landslide dam (Diexi landslide, photo by Zhaoyin Wang in 2006).

of landslides is promoted (Gonzalez-Diez et al., 1999; Lacoste et al., 2011; Larsen and Montgomery, 2012; Doi et al., 2020). Rapid incision steepens hillslope to critical conditions that followed by an increase in mass movement from slope to river channel or even formation of knickpoints, e.g., landslide barrier dams (Ouimet et al., 2008; Dahlquist et al., 2018). In turn, slope gradient tends to reach a stable level as a result of the increase of sediment supplying to river and reduction of bed incision rate, which contributes to a steady-state topography (Mudd and Furbish, 2007; Wohl, 2010; Li et al., 2021). It is also indicated that mass movement rate is highly correlated to incision rate (Larsen and Montgomery, 2012), implying that stream bed incision could be a driving force for hillslope morphology (Mudd and Furbish, 2007; Korup et al., 2010; Chang et al., 2018).

Previous studies on the relationship between stream bed incision and hillslope evolution mainly focus on basin- or orogeny-scale (Sidorchuk, 2006; Mudd and Furbish, 2007; Korup et al., 2010), rarely reveal the situation of small watersheds (Reinhardt et al., 2007; Larsen and Montgomery, 2012; Egholm et al., 2013; Yanites et al.,
2013; Messager et al., 2014). More specifically, the relationship between slope failure or landslides and stream bed incision is rarely quantified for small watersheds, which deserves further study.

Based on preliminary field observations, we designed and conducted laboratory experiments to specifically study the critical conditions and mechanisms for landslides triggered by stream bed incision. The first-order tributaries along the margin of Qinghai-Tibetan Plateau were referred when we designed the flume experiments. The aim of our study is 1) to explore the topography change of the slope along with aggravation of stream bed incision, 2) to reveal the critical conditions for landslide occurrence, i.e., thresholds of effective incision depth and potential landslide energy. To achieve these goals, steady flow and no sediment feed conditions were applied in the experiments for the observation of the topography variation of channel bank as stream bed incised. The volume of landslide, stream bed incision and potential landslide energy were recorded and analyzed, then, their relation was revealed and interpreted. 

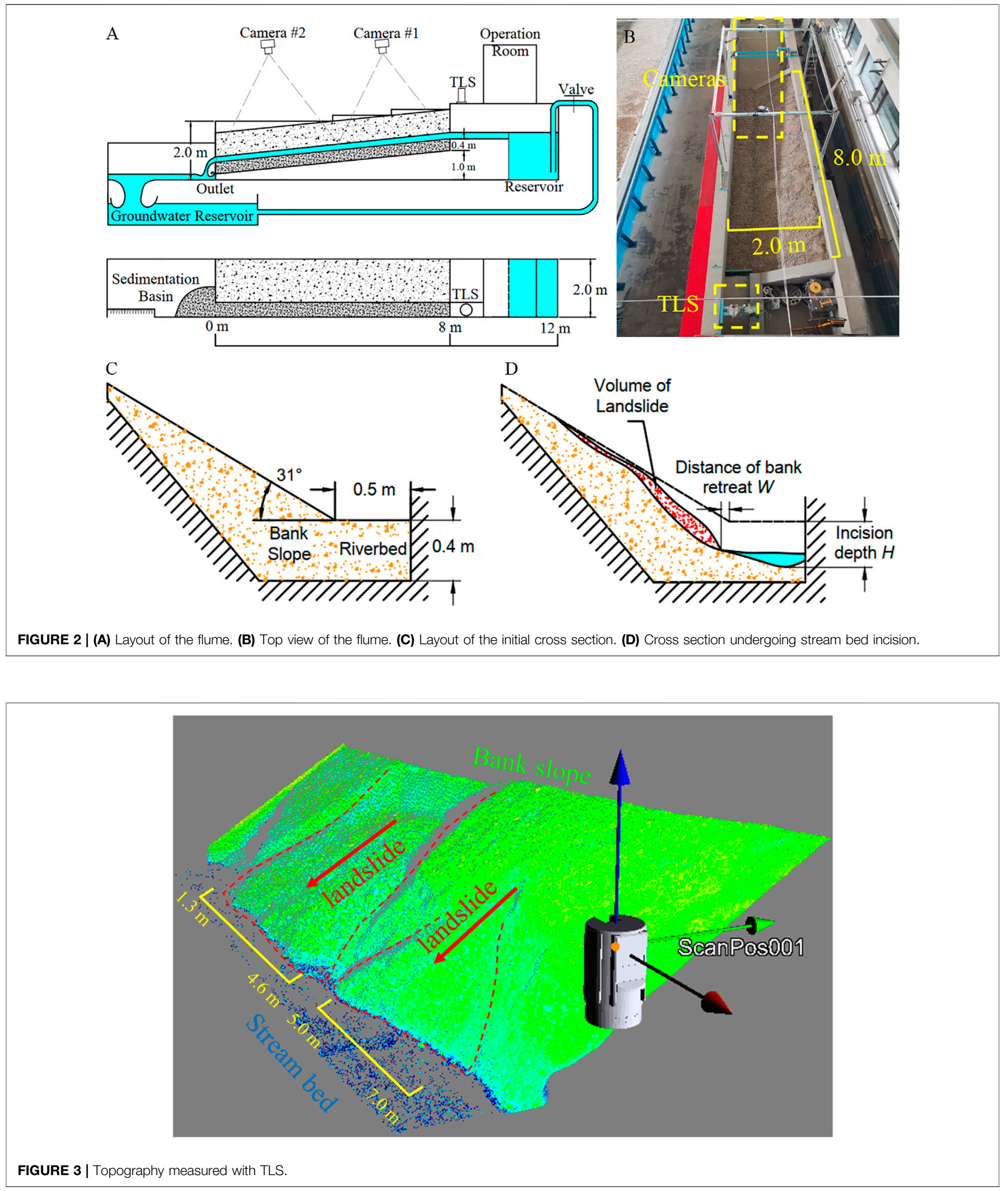


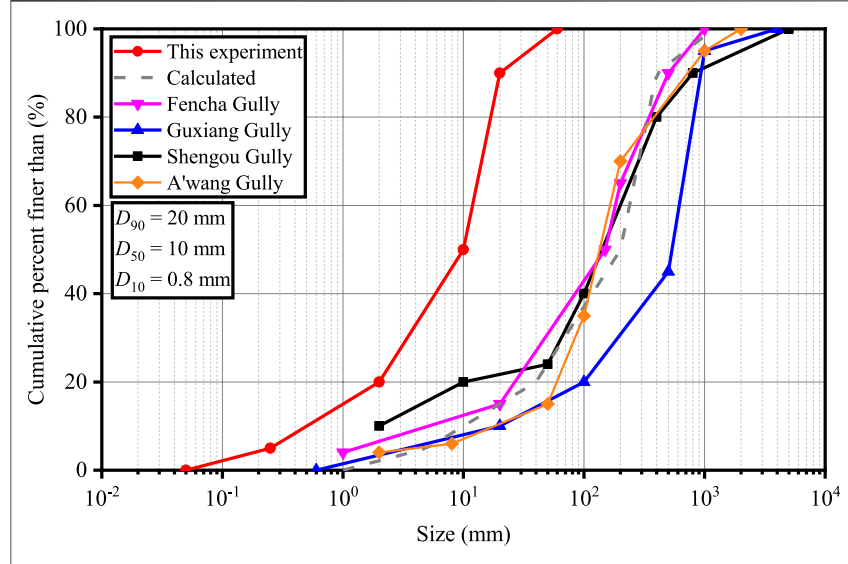

FIGURE 4 | Grain size distributions of sediment used in the experiment and calculated size distribution curve, and size distributions of sediment from the Fencha, Guxiang, Shengou and A'wang gullies.

\section{FLUME EXPERIMENTS}

Flume experiments were carried out in State Key Laboratory of Hydroscience and Engineering, Tsinghua University, Beijing, China. Figure 2A shows that the flume is $12 \mathrm{~m}$ long and $2 \mathrm{~m}$ wide with brick walls, and equipped with a recycled flow system, a reservoir and an operation room. The water pump was controlled through a frequency converter, which maintained the flow steady, and a flowmeter was used for indicating the flow discharge. An $8 \mathrm{~m}$ long section of the flume was designed to simulate a field gully. A sedimentation basin was set at the outlet of the flume.

The process of stream bed incision and landslides was recorded with the Terrestrial Laser Scanner (TLS) and two cameras, as shown in Figure 2B. The TLS (RIEGL VZ-1000, made in Austria) was set on a fixed platform upstream, $0.28 \mathrm{~m}$ from the left wall and $2.0 \mathrm{~m}$ high from the ground, to measure the on-time surface topography of the bank slope and stream bed (Figure 3). The TLS was set to scan automatically at an interval of $1 \mathrm{~min}$. The two cameras (Canon 80D), fixed on a platform that was $2.2 \mathrm{~m}$ high over the flume, located at 2.0 and $4.2 \mathrm{~m}$ upstream of the flume outlet, respectively, were controlled by the EOS Utility.

The flume experiments were designed to generally simulate the Fencha Gully (Figure 1A, $102^{\circ} 16^{\prime} 32^{\prime \prime} \mathrm{E}, 28^{\circ} 6^{\prime} 42^{\prime \prime} \mathrm{N}$ ). The Fencha Gully is located in the midstream region of the Reshuihe River, which is a tributary of the Anning River in Sichuan Province. The study site is developing on a huge landslide body and the banks of the gully are composed of loose sediment. Landslides occur frequently in the gully due to intensive stream bed incision. The sections with incision and landslides of the gully are mainly straight. A length scale ratio of 1:20 was applied for the experiment. The initial stream width of the flume was $0.5 \mathrm{~m}$, which responded to the gully width of about $10 \mathrm{~m}$. The right flume bank was set at $31^{\circ}$, which is roughly equal to the bank slope of the Fencha Gully (Figure 2C). The gradient of the stream bed in the flume was 0.1 , which was roughly the same as the bed gradient of the Fencha Gully. The thickness of the loose sediment layer on the bank was $0.1-0.7 \mathrm{~m}$ and the thickness of the stream bed was $0.4 \mathrm{~m}$ in the flume.
Figure 4 shows the size distributions of sediments of the Fencha Gully, the Guxiang Gully (Lyu et al., 2017), the Shengou Gully and A'wang Gully (Zhang, 2017, Zhang et al., 2018). All the four gullies are in the Hengduan Mountain and are debris flow gullies with landslides from their slopes. The size distribution of sediment used in the experiment is shown in figure. A size distribution curve calculated with a length scale ratio 1:20 from the experiment sediment is also shown (gray dot line), which is very close to the size distribution of the Fencha Gully. The density $\rho$ of the loose sediment is $1,660 \mathrm{~kg} / \mathrm{m}^{3}$. The discharge scale ratio is $1: 20^{2.5}$ and the volume scale ratio is $1: 20^{3}$ based on Froude similarity (Finnemore and Franzini, 2003).

\section{RESULTS AND DISCUSSION}

Flume experiments were conducted to study the impact of stream bed incision on the bank stability and the mechanism of landslides. Table 1 lists the main results of nine runs of experiments. The flow discharge $(Q)$, the location of the landslide section, the total volume of landslides $\left(V_{\text {total }}\right)$ in each run, and the total volume of sediment transported to the downstream end of the flume $\left(S_{\mathrm{m}}\right)$ are listed. The corresponding discharge $\left(Q_{\mathrm{p}}\right)$ in the field and landslide volume $\left(V_{\mathrm{p}}\right)$ are calculated with the discharge scale ratio and the volume scale ratio are listed in the table as well.

\section{Incision, Landslides and Sediment Transportation}

The stream flow scoured the bed and caused bed incision in the experiment. Figure 5 shows the incision processes of three runs of the experiment with different discharges.

For each run, the upstream $(8.0 \mathrm{~m})$, middle $(4.0 \mathrm{~m})$, and downstream $(0.0 \mathrm{~m})$ are incised quickly at first and tend to be stable later. The upstream section is incised deeper than the middle and downstream, since the latter is supplied with sediment from the upstream reach.

It was observed that numerous landslides occurred following stream bed incision and lateral erosion at the bank toe. Figure 6A shows a landslide in the experiment. As a comparison, a landslide occurred in the Fencha Gully with similar characteristics about 20 times larger in the length scale is shown in Figure 6B.

The sediment eroded from the bed and the bank was transported, in the form of bed load motion, to the downstream end of the flume. There was almost no suspended load motion in the experiment because the sediment is coarse and non-cohesive. The rate of sediment transportation was measured at the outlet of the flume with the sedimentation basin. The scouring rate of sediment from the bed is defined as the weight of sediment scoured from the stream bed per area per time. Figure 7 shows the varying processes of the scouring rate $\left(R_{\text {scour }}\right)$, the rate of sediment transportation $(S)$ and volume of landslide ( $V$, see Figure 2D) in six runs, which are calculated from the variation of the topography in the flume and the sedimentation basin measured with TLS. In the runs with large flow discharge (runs 3-1, 3-2, and 3-3) the volume and frequency of landslide are larger than that with low discharge (run 1-1). 
TABLE 1 | Experimental results.

\begin{tabular}{|c|c|c|c|c|c|c|c|c|}
\hline \multirow[t]{2}{*}{ Run } & \multirow[t]{2}{*}{$Q(\mathrm{~L} / \mathrm{s})$} & \multirow[t]{2}{*}{ Landslide section (m) } & \multirow[t]{2}{*}{$V_{\text {total }}\left(\mathrm{m}^{3}\right)$} & \multicolumn{2}{|c|}{$S_{m}\left(m^{3}\right)$} & \multirow[t]{2}{*}{$\mathbf{T}(\min )$} & \multirow[t]{2}{*}{$Q_{p}\left(m^{3} / s\right)$} & \multirow[t]{2}{*}{$V_{p}\left(m^{3}\right)$} \\
\hline & & & & Weighed & By TLS & & & \\
\hline $1-1$ & 4.17 & $3.6-5.2$ & 0.308 & 2.48 & 2.57 & 59 & 7.46 & 2,464 \\
\hline $1-2$ & & $3.0-5.0$ & 0.160 & 2.56 & 2.51 & 53 & & 1,280 \\
\hline $1-3$ & & $2.4-3.2$ & 0.083 & 2.42 & 2.32 & 46 & & 664 \\
\hline \multirow[t]{2}{*}{$2-1$} & 5.56 & 1.0-3.4 (\#1) & 0.416 & 1.98 & 2.07 & 57 & 9.95 & 3,328 \\
\hline & & $3.4-6.0$ (\#2) & 0.154 & & & & & 1,232 \\
\hline \multirow[t]{2}{*}{$2-2$} & & $3.0-4.0(\# 1)$ & 0.084 & 2.36 & 2.43 & 46 & & 672 \\
\hline & & $4.0-5.7$ (\#2) & 0.104 & & & & & 832 \\
\hline \multirow[t]{2}{*}{$2-3$} & & 2.0-4.0 (\#1) & 0.382 & 2.73 & 2.68 & 51 & & 3,056 \\
\hline & & $4.0-5.0(\# 2)$ & 0.200 & & & & & 1,600 \\
\hline $3-1$ & 6.94 & $2.0-4.5$ & 0.337 & 2.60 & 2.52 & 37 & 12.41 & 2,696 \\
\hline $3-2$ & & $1.0-4.0$ & 0.384 & 2.54 & 2.58 & 32 & & 3,072 \\
\hline \multirow[t]{2}{*}{$3-3$} & & $1.3-4.6(\# 1)$ & 1.034 & 2.99 & 3.05 & 41 & & 8,272 \\
\hline & & 5.0-7.0 (\#2) & 0.247 & & & & & 1976 \\
\hline
\end{tabular}
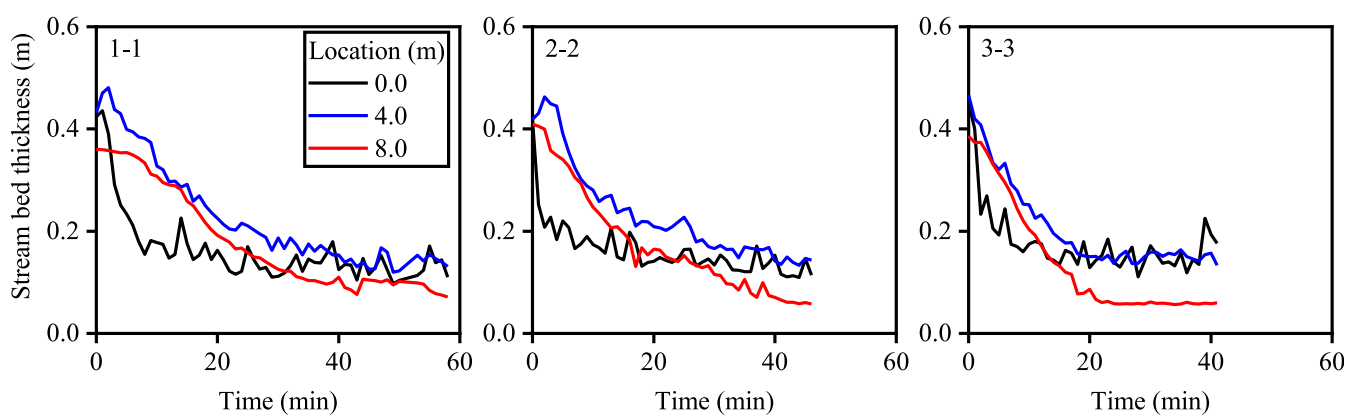

FIGURE 5 | Incision processes of runs 1-1, 2-2, and 3-3.
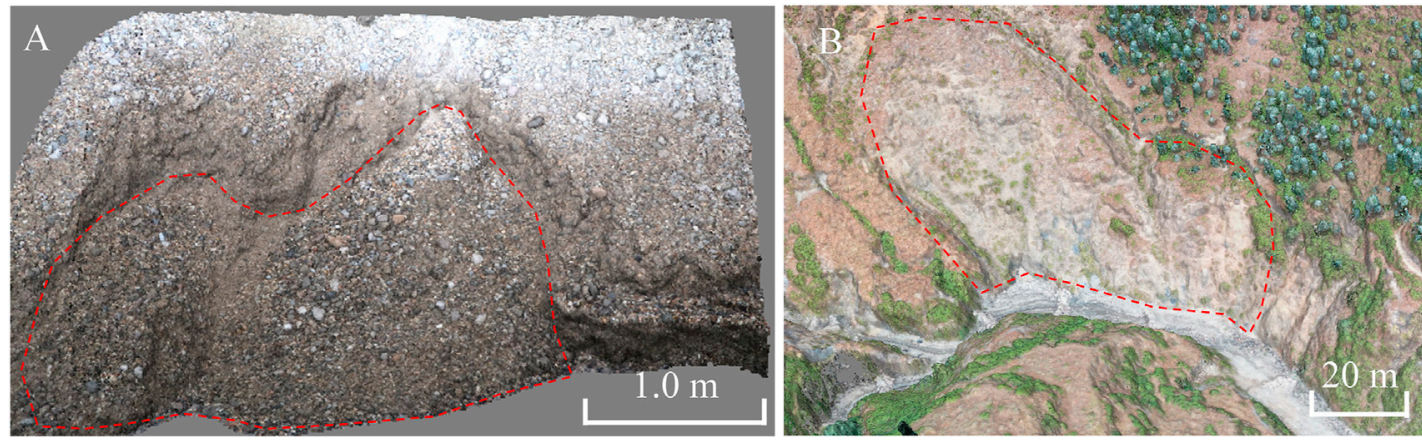

FIGURE 6 | (A) A landslide in the flume experiment. (B) A landslide in the Fencha Gully with similar characteristics.

The bed souring is influenced by many factors including flow discharge, incoming sediment from upstream, bed slope and particle size. The scouring rate $\left(R_{\text {scour }}\right)$ fluctuates because landslides affect the rate (Figure 5). In the initial stage (in light gray area), the high $R_{\text {scour }}$ results in a high $S$ (Shao et al., 2002), whereas the frequency and scale of landslides are relatively low during this time. As the test goes on, the stream bed is scoured to a deep position, landslides occur frequently with a large scale and high frequency (in dark gray area).

The flow was maintained along the left wall in the upstream section, and it flew to the right and scoured the right bank. Most landslides occurred mainly in section $3 \mathrm{~m}$ downstream of the entrance (see landslide section given in Table 1), because the stream bed incision and lateral bank erosion were more obvious than that in other sections. It was observed that lateral bank 

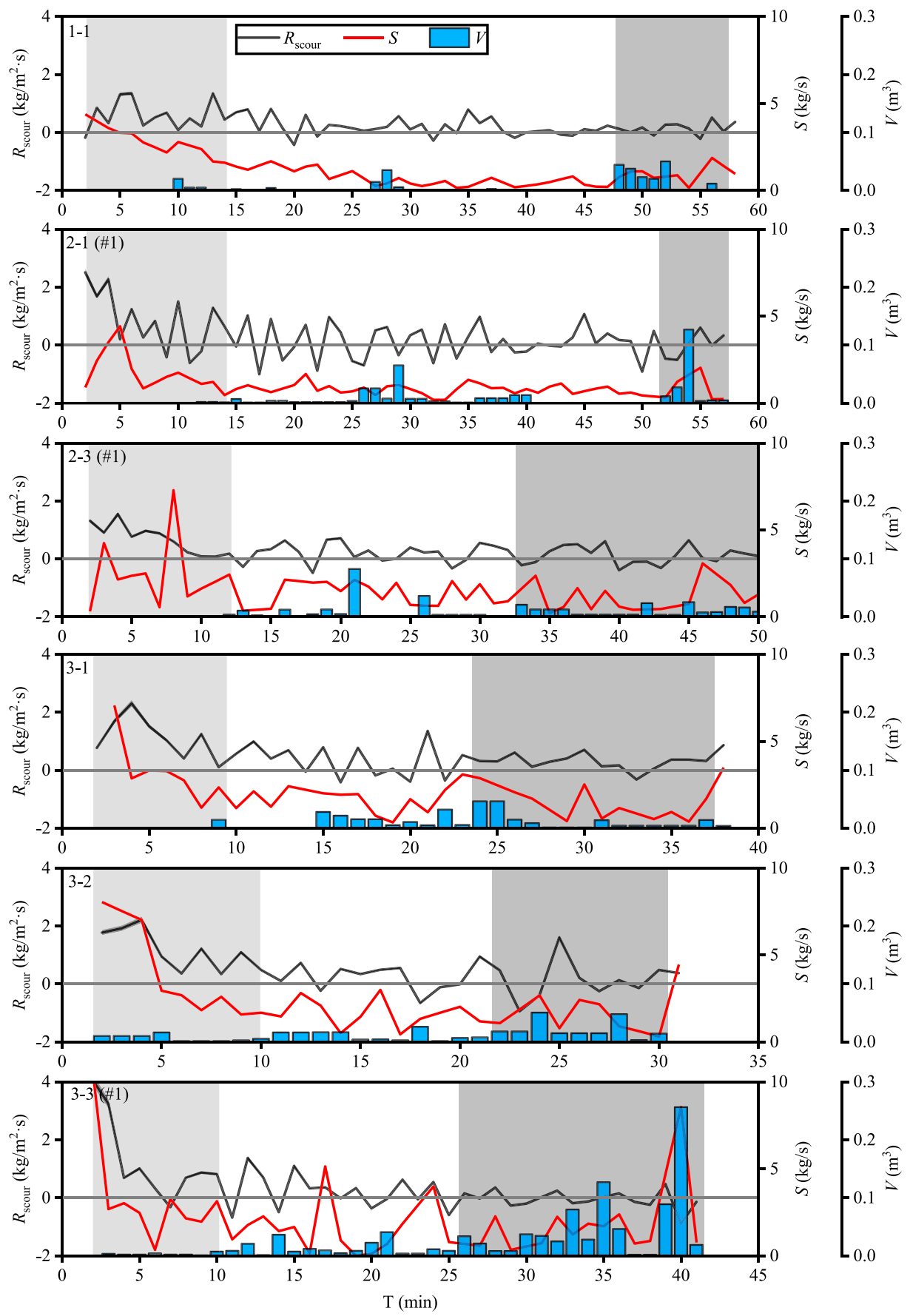

FIGURE 7 | Scouring rate $\left(R_{\text {scour }}\right)$, rate of sediment transportation $(S)$ and volume of landslide $(V)$ at the main landslide section.

erosion played the same role as bed incision to cause landslides. Therefore, an additional bed incision depth in vertical direction can be calculated from the horizontal distance of bank retreat $W$, as discussed in the next section.

\section{Critical Conditions for Landslides}

The critical conditions for landslides are associated with the volume of landslide, incision depth and the potential landslide energy (Wang et al., 2012, Wang et al., 2015), which depends on the slope angle, incision depth and lateral bank erosion. Bed incision is the dominant triggering mechanism for landslides in the study area. Figure $\mathbf{8 A}$ shows the accumulated volume of landslides of each section, $V_{\mathrm{L}}$, as a function of the average incision depth $H$ (see Figure 2D). The accumulated volume increases with incision depth and grows suddenly and sharply as the incision depth exceeds a critical value. 

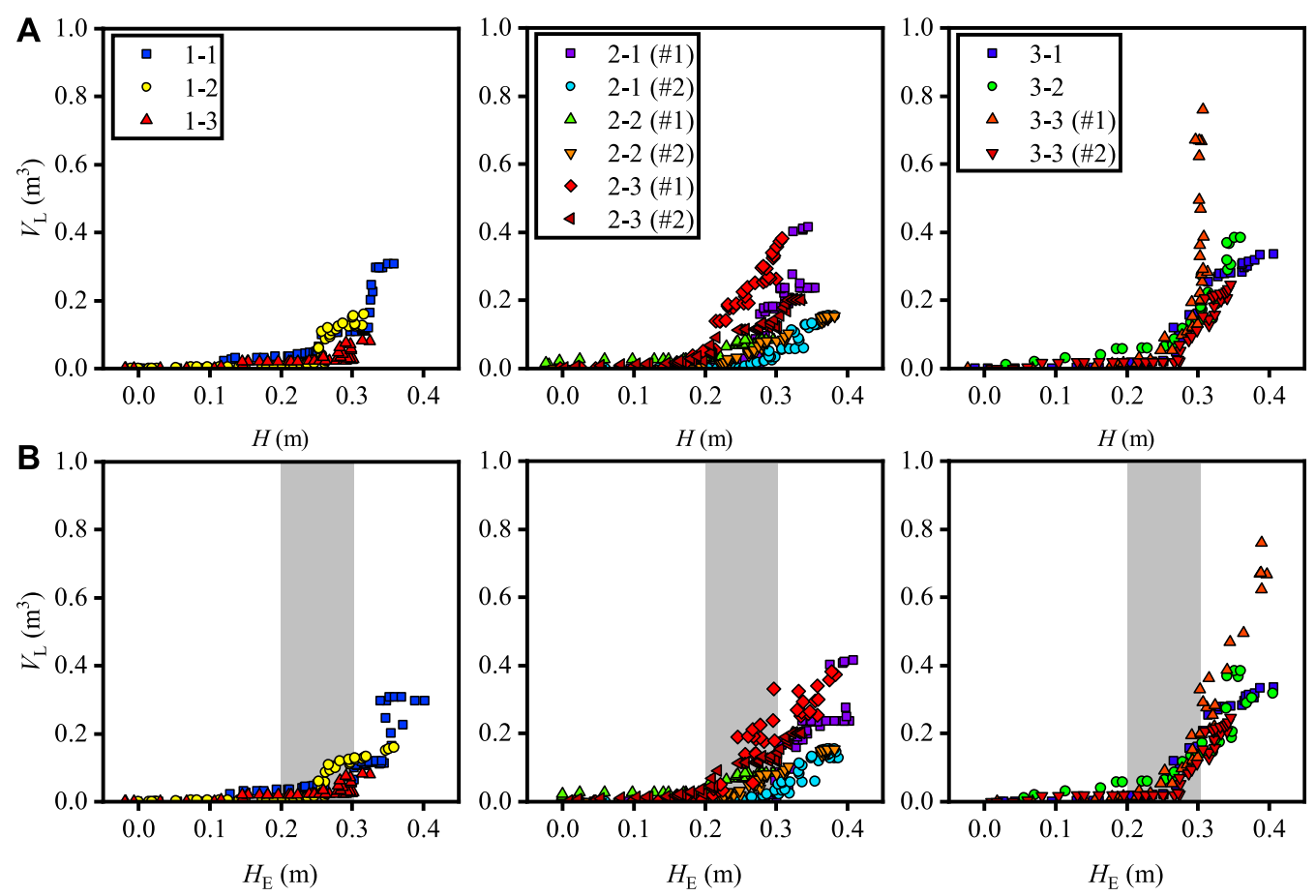

FIGURE 8 | (A) Accumulated volume of landslides $V_{L}$ Vs. incision depth $H$. (B) Accumulated volume of landslides $V_{L}$ vs. effective incision depth $H_{E}$.

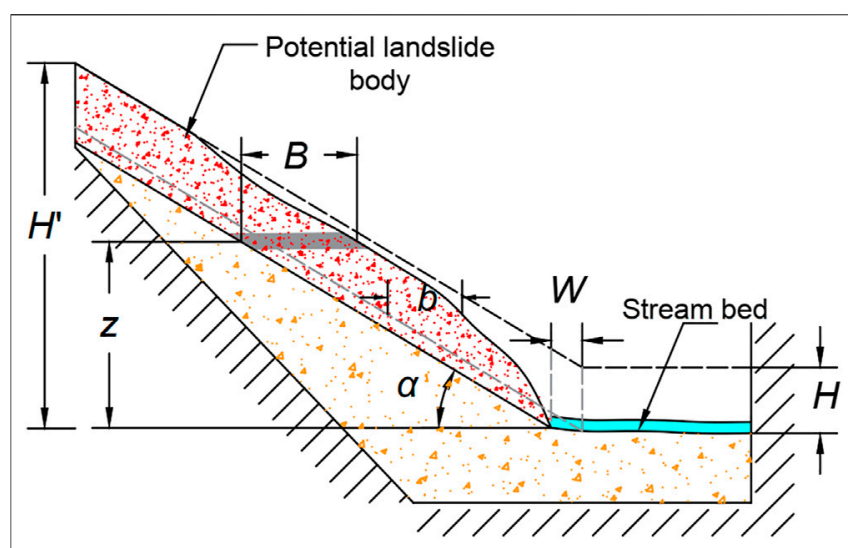

FIGURE 9 | Schematic diagram of effective incision and potential landslide energy.

Lateral bank erosion is another important triggering mechanism for landslides (Wang et al., 2009; Lévy et al., 2012; Malatesta et al., 2017). An effective incision depth denoted as $H_{\mathrm{E}}$ combines stream bed incision and lateral bank erosion (see Figure 9), which can be expressed as follows,

$$
H_{E}=H+W \tan \alpha
$$

where $H$ is the incision depth, $W$ is the distance of bank retreat and $\alpha$ is the angle of repose, which is $31^{\circ}$ in this study.

Figure 8B shows an interval of critical effective incision depth for sharply increasing accumulated volume of landslides. The interval of critical effective incision depth $H_{\mathrm{E}}$ is $0.2-0.3 \mathrm{~m}$ (i.e., $4.0-6.0 \mathrm{~m}$ by length scale). When $H_{\mathrm{E}}$ is less than this range, the $V_{\mathrm{L}}$ is generally less than $0.05 \mathrm{~m}^{3}$, which is mainly caused by water erosion rather than gravitational erosion.

As shown in Figure 9, the potential landslide energy $E$ is defined as the potential energy of loose sediment per length on the bank slope over a surface of repose angle to stream bed, which is given by:

$$
E=\int_{0}^{H^{\prime}} \gamma_{s} B(z) z d z
$$

where $H^{\prime}$ is the vertical distance from the top of a landslide to the stream bed, $\gamma_{s}$ is the specific weight of sediment, $B$ is the width of loose sediment over the surface of repose angle in horizontal direction, and $z$ is the vertical coordinate. The initial bank slope of $31^{\circ}$ is used as the repose angle in the calculation of the potential landslide energy $E$.

Figures 10A,B show the accumulated volume of landslides $V_{\mathrm{L}}$, and volume of each landslide $V$ as function of the potential landslide energy $E$, respectively. The landslide scale increases as the stream bed incises and potential energy increases (Wang et al., 2021). A critical value of $E$ is found at $2,800 \mathrm{kgm} / \mathrm{s}^{2}$, above which $V_{\mathrm{L}}$ increases abruptly. This critical value in the Fencha Gully is $2.24 \times 10^{4} \mathrm{t} \cdot \mathrm{m} / \mathrm{s}^{2}$ according to the scale ratio of energy per length of $1: 20^{3}$.

The experimental results are compared with field measurements of three landslides in the Fencha Gully, the locations of which are shown in Figure 11. Table 2 lists the measured data and potential landslide energy calculated with Eq. 

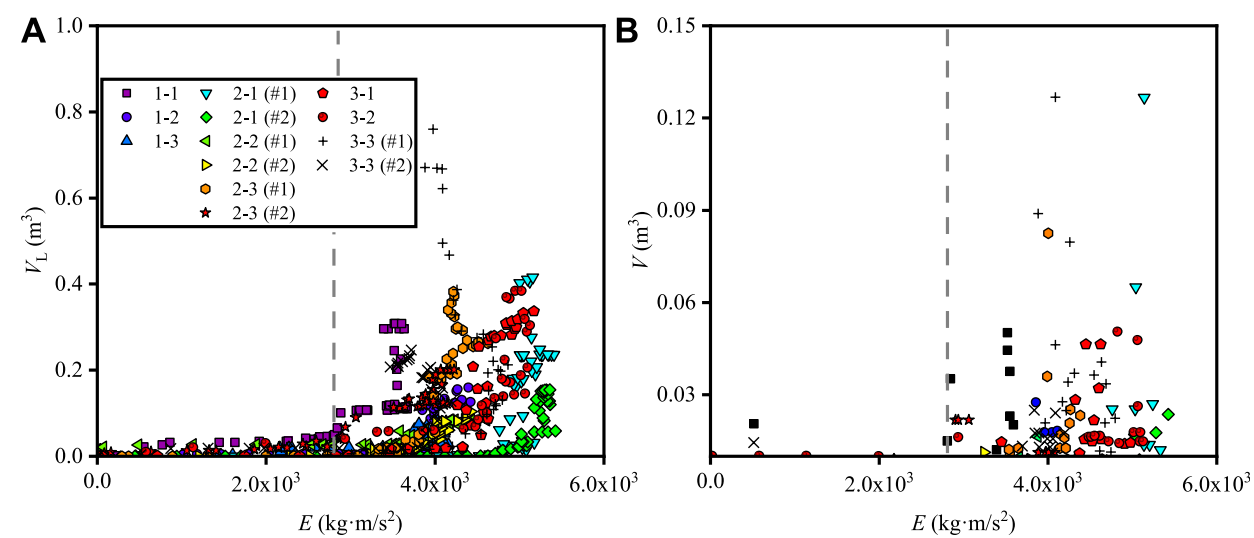

FIGURE 10 | (A) Accumulated volume of landslides $V_{L}$ vs. potential landslide energy $E$. (B) Volume of landslide vs. potential landslide energy $E$.

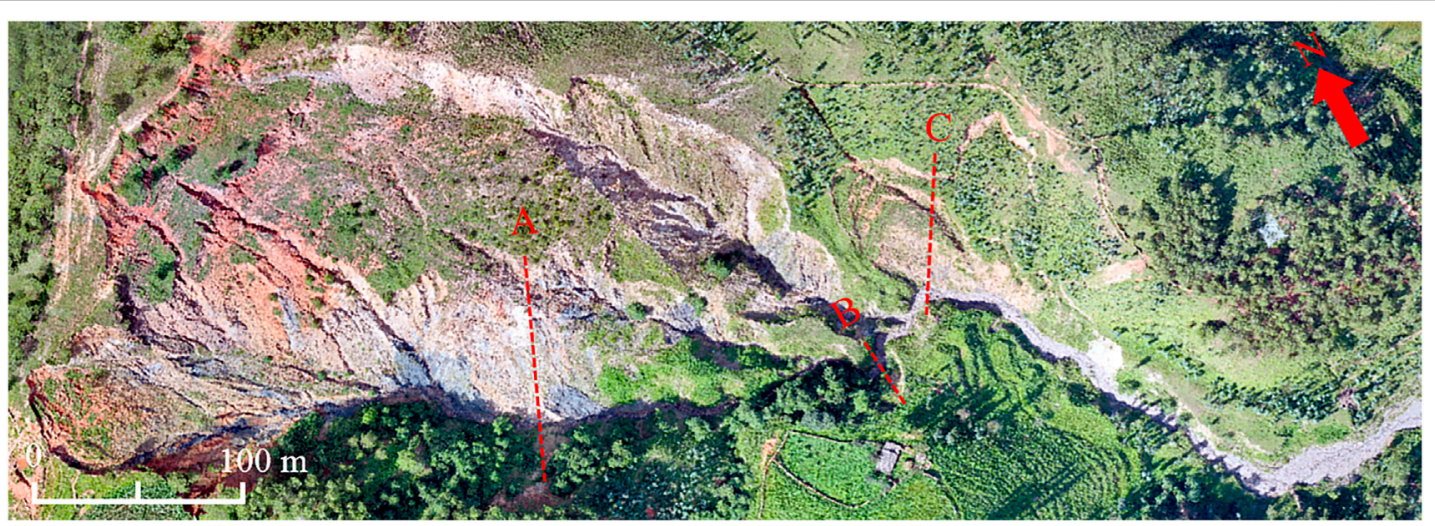

FIGURE 11 | The locations of the computed cross sections of landslides in the Fencha Gully.

\begin{tabular}{|c|c|c|c|c|c|}
\hline Landslide & $\begin{array}{c}\text { Volume of } \\
\text { landslide }\left(\mathrm{m}^{3}\right)\end{array}$ & $\begin{array}{l}\text { Incision depth } \\
\text { (m) }\end{array}$ & $\begin{array}{c}\text { Bank slope } \\
\text { angle }\left({ }^{\circ}\right)\end{array}$ & $E\left(\mathrm{t} \cdot \mathrm{m} / \mathrm{s}^{2}\right)$ & $\begin{array}{c}\text { Critical } E \\
\left(\mathrm{t} \cdot \mathrm{m} / \mathrm{s}^{2}\right)\end{array}$ \\
\hline$A$ & $1.2 \times 10^{6}$ & 6.0 & 38.4 & $8.89 \times 10^{4}$ & $2.24 \times 10^{4}$ \\
\hline B & $5.0 \times 10^{3}$ & 4.5 & 37.8 & $5.73 \times 10^{4}$ & \\
\hline C & $1.2 \times 10^{5}$ & 4.3 & 35.0 & $4.61 \times 10^{4}$ & \\
\hline
\end{tabular}

2. The potential landslide energy is larger than the critical value, and the incision depth is critical, which agrees with the results in the experiments.

\section{CONCLUSION}

An experimental study of landslides was done with a flume of high bed gradient and bank slopes consisting of loose sediment, to study the mechanism of landslides induced by stream bed incision and the increasing potential energy for landslides. The experiments were designed to generally simulate the Fencha
Gully. The results show that stream bed incision and lateral bank erosion occur due to water flow scouring. Landslides or bank failures are induced as a result of stream bed incision and lateral bank erosion.

The mechanism of landslides is related to incision depth and potential landslide energy. A critical value of effective incision depth coupling vertical incision and lateral bank erosion for landslides is illustrated. Landslides increase sharply if the effective incision depth is higher than the critical value, which is $4.0-6.0 \mathrm{~m}$ in the Fencha Gully. The critical value of potential landslide energy in the Fencha Gully is calculated with energy scale ratio $1: 20^{3}$, which is $2.24 \times 10^{4} \mathrm{t} \cdot \mathrm{m} / \mathrm{s}^{2}$. Three landslides caused 
by stream bed incision and lateral bank erosion in the Fencha Gully are measured, and compared with the critical conditions obtained from the experiments. The potential landslide energy is larger than the critical value, and the incision depth is critical, which agrees well with the results in the experiments.

\section{DATA AVAILABILITY STATEMENT}

The original contributions presented in the study are included in the article, further inquiries can be directed to the corresponding author.

\section{AUTHOR CONTRIBUTIONS}

$\mathrm{KH}$ carried out the experiments and analyzed the data; MX initiated, conceptualized and sponsored this work; ZW assisted with experimental guidance and data analysis.

\section{REFERENCES}

Azañón, J. M., Azor, A., Pérez-Peña, J. V., and Carrillo, J. M. (2005). Late Quaternary large-scale rotational slides induced by river incision: the Arroyo de Gor area (Guadix basin, SE Spain). Geomorphology. 69 (1-4), 152-168. doi:10.1016/j.geomorph.2004.12.007

Berger, C., McArdell, B. W., and Schlunegger, F. (2011). Direct Measurement of Channel Erosion by Debris Flows, Illgraben, Switzerland. J. Geophys. Res. 116, a-n. doi:10.1029/2010JF001722

Chang, K.-J., Chan, Y.-C., Chen, R.-F., and Hsieh, Y.-C. (2018). Geomorphological Evolution of Landslides Near an Active normal Fault in Northern Taiwan, as Revealed by Lidar and Unmanned Aircraft System Data. Nat. Hazards Earth Syst. Sci. 18, 709-727. doi:10.5194/nhess-18-709-2018

Dahlquist, M. P., West, A. J., and Li, G. (2018). Landslide-driven Drainage divide Migration. Geology. 46 (5), 403-406. doi:10.1130/G39916.1

Doi, I., Matsuura, S., Osawa, H., Shibasaki, T., and Tosa, S. (2020). Effects of Coastal Erosion on Landslide Activity Revealed by Multi-sensor Observations. Earth Surf. Process. Landforms. 45, 2291-2299. doi:10. 1002/esp.4880

Egholm, D. L., Knudsen, M. F., and Sandiford, M. (2013). Lifespan of Mountain Ranges Scaled by Feedbacks between Landsliding and Erosion by Rivers. Nature. 498, 475-478. doi:10.1038/nature12218

Finnemore, E. J., and Franzini, J. B. (2003). Fluid Mechanics with Engineering Applications. Tenth edition. Beijing. China: McGraw-Hill and Tsinghua Press, 237-238.

Gonzalez-Diez, A., Remondo, J., Diaz de Teran, J., and Cendrero, A. (1999). A Methodological Approach for the Analysis of the Temporal Occurrence and Triggering Factors of Landslides. Geomorphology. 30, 95-113. doi:10.1016/ S0169-555X(99)00047-1

Hobley, D. E. J., Sinclair, H. D., Mudd, S. M., and Cowie, P. A. (2011). Field Calibration of Sediment Flux Dependent River Incision. J. Geophys. Res. 116, F04017. doi:10.1029/2010JF001935

Kirschbaum, D., Stanley, T., and Zhou, Y. (2015). Spatial and Temporal Analysis of a Global Landslide Catalog. Geomorphology. 249, 4-15. doi:10.1016/j. geomorph.2015.03.016

Korup, O., Densmore, A. L., and Schlunegger, F. (2010). The Role of Landslides in Mountain Range Evolution. Geomorphology. 120 (1-2), 77-90. doi:10.1016/j. geomorph.2009.09.017

Lacoste, A., Vendeville, B. C., and Loncke, L. (2011). Influence of Combined Incision and Fluid Overpressure on Slope Stability: Experimental Modelling and Natural Applications. J. Struct. Geology. 33 (4), 731-742. doi:10.1016/j.jsg. 2011.01.016

\section{FUNDING}

The authors gratefully acknowledge the financial support of the Chinese Academy of Sciences (XDA23090401), the Natural Science Foundation of China (41790434, 41941019, 51639005, 51809086), and the Second Tibetan Plateau Scientific Expedition and Research Program (STEP) (2019QZKK0903).

\section{ACKNOWLEDGMENTS}

We thank many people for their guidance on experiments and data processing including Yifei Cui, Chendi Zhang, and Ruiyu Wang from Tsinghua University, and Liqun Lyu from Beijing Forestry University. Additional thanks to Chenyang Wang, Yunlong Lei from Tsinghua University for their assistance in collecting experimental and field data.

Larsen, I. J., and Montgomery, D. R. (2012). Landslide Erosion Coupled to Tectonics and River Incision. Nat. Geosci. 5, 468-473. doi:10.1038/ngeo1479

Lévy, S., Jaboyedoff, M., Locat, J., and Demers, D. (2012). Erosion and Channel Change as Factors of Landslides and valley Formation in Champlain Sea Clays: The Chacoura River, Quebec, Canada. Geomorphology. 145-146, 12-18. doi:10. 1016/j.geomorph.2011.09.014

Li, Y., Meng, X., Stevens, T., Armitage, S., Bian, S., Chen, G., et al. (2021). Distinct Periods of Fan Aggradation and Incision for Tributary Valleys of Different Sizes along the Bailong River, Eastern Margin of the Tibetan Plateau. Geomorphology. 373, 107490. doi:10.1016/j.geomorph.2020.107490

Lyu, L., Wang, Z., Cui, P., and Xu, M. (2017). The Role of Bank Erosion on the Initiation and Motion of Gully Debris Flows. Geomorphology. 285, 137-151. doi:10.1016/j.geomorph.2017.02.008

Malatesta, L. C., Prancevic, J. P., and Avouac, J.-P. (2017). Autogenic Entrenchment Patterns and Terraces Due to Coupling with Lateral Erosion in Incising Alluvial Channels. J. Geophys. Res. Earth Surf. 122, 335-355. doi:10. 1002/2015JF003797

Messager, G., Hassani, R., and Nivière, B. (2014). Mechanical Analysis of a Natural Example of Onland Gravity Gliding: The Role of River Incision and Deposition. J. Geophys. Res. Earth Surf. 119, 1581-1603. doi:10.1002/2013JF003062

Mudd, S. M., and Furbish, D. J. (2007). Responses of Soil-Mantled Hillslopes to Transient Channel Incision Rates. J. Geophys. Res. 112, F03S18. doi:10.1029/ 2006JF000516

Ouimet, W. B., Whipple, K. X., Crosby, B. T., Johnson, J. P., and Schildgen, T. F. (2008). Epigenetic Gorges in Fluvial Landscapes. Earth Surf. Process. Landforms. 33, 1993-2009. doi:10.1002/esp.1650

Ouimet, W. B., Whipple, K. X., and Granger, D. E. (2009). Beyond Threshold Hillslopes: Channel Adjustment to Base-Level Fall in Tectonically Active Mountain Ranges. Geology. 37 (7), 579-582. doi:10.1130/G30013A.1

Ouimet, W. B., Whipple, K. X., Royden, L. H., Sun, Z., and Chen, Z. (2007). The Influence of Large Landslides on River Incision in a Transient Landscape: Eastern Margin of the Tibetan Plateau (Sichuan, China). Geol. Soc. America Bull. 119 (11-12), 1462-1476. doi:10.1130/B26136.1

Ouimet, W., Whipple, K., Royden, L., Reiners, P., Hodges, K., and Pringle, M. (2010). Regional Incision of the Eastern Margin of the Tibetan Plateau. Lithosphere. 2 (1), 50-63. doi:10.1130/L57.1

Reinhardt, L. J., Bishop, P., Hoey, T. B., Dempster, T. J., and Sanderson, D. C. W. (2007). Quantification of the Transient Response to Base-Level Fall in a Small Mountain Catchment: Sierra Nevada, Southern Spain. J. Geophys. Res. 112, F03S05. doi:10.1029/2006JF000524

Safran, E. B., Bierman, P. R., Aalto, R., Dunne, T., Whipple, K. X., and Caffee, M. (2005). Erosion Rates Driven by Channel Network Incision in the Bolivian Andes. Earth Surf. Process. Landforms. 30, 1007-1024. doi:10.1002/esp.1259 
Shao, S. D., Lo, E. Y. M., and Wang, G. Q. (2002). Simulation of Fan Formation Using a Debris Mass Model. J. Hydraul. Res. 40 (4), 425-433. doi:10.1080/ 00221680209499885

Sidorchuk, A. (2006). Stages in Gully Evolution and Self-Organized Criticality. Earth Surf. Process. Landforms 31, 1329-1344. doi:10.1002/esp.1334

Wang, Z.-Y., Lee, J. H. W., and Melching, C. S. (2015). River Dynamics and Integrated River Management. Berlin: Springer. doi:10.1007/978-3-64225652-3

Wang, Z., Chen, Z., Yu, S., Zhang, Q., Wang, Y., and Hao, J. (2021). Erosioncontrol Mechanism of Sediment Check Dams on the Loess Plateau. Int. J. Sediment Res. (in press) doi:10.1016/j.ijsrc.2021.02.002

Wang, Z., Cui, P., and Wang, R. (2009). Mass Movements Triggered by the Wenchuan Earthquake and Management Strategies of Quake Lakes. Int. J. River Basin Management. 7 (4), 391-402. doi:10.1080/15715124.2009.9635397

Wang, Z., Cui, P., Yu, G.-a., and Zhang, K. (2012). Stability of Landslide Dams and Development of Knickpoints. Environ. Earth Sci. 65, 1067-1080. doi:10.1007/ s12665-010-0863-1

Whipple, K. X. (2004). Bedrock Rivers and the Geomorphology of Active Orogens. Annu. Rev. Earth Planet. Sci. 32, 151-185. doi:10.1146/annurev.earth.32. 101802.120356

Wohl, E. (2010). Mountain Rivers Revisited. Washington, DC: American Geophysical Union. doi:10.1029/WM019

Xu, M., Wang, Z., Qi, L., Liu, L., Liu, L., and Zhang, K. (2012). Disaster Chains Initiated by the Wenchuan Earthquake. Environ. Earth Sci. 65, 975-985. doi:10. 1007/s12665-011-0905-3
Yanites, B. J., Ehlers, T. A., Becker, J. K., Schnellmann, M., and Heuberger, S. (2013). High Magnitude and Rapid Incision from River Capture: Rhine River, Switzerland. J. Geophys. Res. Earth Surf. 118, 1060-1084. doi:10.1002/jgrf.20056

Zhang, C. (2017). Study on the Stability of Step-Pool System. Beijing, China: Tsinghua University, Doctor of Philosophy dissertation

Zhang, C., Xu, M., Hassan, M. A., Chartrand, S. M., and Wang, Z. (2018) Experimental Study on the Stability and Failure of Individual Step-Pool. Geomorphology. 311, 51-62. doi:10.1016/j.geomorph.2018.03.023

Zhao, S., Chigira, M., and Wu, X. (2019). Gigantic Rockslides Induced by Fluvial Incision in the Diexi Area along the Eastern Margin of the Tibetan Plateau. Geomorphology. 338, 27-42. doi:10.1016/j.geomorph.2019.04.008

Zhou, J.-w., Cui, P., and Hao, M.-h. (2016). Comprehensive Analyses of the Initiation and Entrainment Processes of the 2000 Yigong Catastrophic Landslide in Tibet, China. Landslides. 13 (1), 39-54. doi:10.1007/s10346-014-0553-2

Conflict of Interest: The authors declare that the research was conducted in the absence of any commercial or financial relationships that could be construed as a potential conflict of interest.

Copyright (c) 2021 Huang, Xu and Wang. This is an open-access article distributed under the terms of the Creative Commons Attribution License (CC BY). The use, distribution or reproduction in other forums is permitted, provided the original author(s) and the copyright owner(s) are credited and that the original publication in this journal is cited, in accordance with accepted academic practice. No use, distribution or reproduction is permitted which does not comply with these terms. 